\title{
Written in the Margins: Reading into Texts
}

\section{寫在抄本的邊綠上: 了解晚清民國時期的平民文化}

This chapter continues the process of examining hand-written chaoben from various points of view. A number of the titles introduced in Chapter 1 and Chapter 2 are again brought up for examination and several newly introduced chaoben are added to the discussion. The goal of this particular chapter is to allow us to read meaning into the "extraneous" or "random" materials we find in chaoben. At first glance, we have seen that the chaoben usually consist of several texts within the same booklet that deal with various subjects. In addition, as illustrated in Chapter 2, comments, observations, and selfpromotion are often written in the margins. Not infrequently, short poems expose some of the attitudes and values of the author or copyist of the booklet. With some regularity we find that the copyist wrote a poem or two of his own creation at the conclusion to his copied text. We can also judge the writing and from it draw conclusions about the degree of formal schooling the copyist received by evaluating not only the quality of calligraphy but the content of the poems or random comments that might have been added in the margins of the copied text. All these observations help us to draw meaning from the booklets that go beyond the surface meaning of the main textual content.

Thus far we have seen that the handwritten chaoben were prepared as reference materials for the professional and personal lives of their author. In the "professional" portions, the author wrote down information that would help him to earn a living. This aspect of the texts had an economic function, in that they were used to help the owner earn a living by allowing him to refer to the information he had copied out. At the same time, the men who copied out these texts often treated them as notebooks, in which all sorts of information the holder considered relevant could be written down. In some cases, it appears the copyist earned money from one occupation, perhaps medicine as in the case of Dr. He in the chaoben Internal and External Medical Complaints [Neiwaike yanke zazheng 內外科眼科雜症]. ${ }^{1}$ discussed below, but was equally

1 Internal and External Medical Complaints [Neiwaike yanke zazheng 內外科眼科雜症] is 8 in $(20.32 \mathrm{~cm}) \mathrm{h} \times 5^{1 / 4}$ in $(13.33 \mathrm{~cm})$ w. Several styles of handwriting and paper of different sizes

(C) RONALD SULESKI, 2018 | DOI:10.1163/9789004361034_005

This is an open access chapter distributed under the terms of the prevailing CC-BY-NC License at the time of publication. 
interested in another topic. In the case of Dr. He it was the practice of religious Daoism. So Dr. He included information on two Daoist religious rituals in his notebook. Thus it is typical to find a number of perhaps seemingly unrelated topics all included in the same chaoben.

It is important to acknowledge these texts as having both a "professional" and a "personal" side. ${ }^{2}$ Taken together, each chaoben can guide us to form a multidimensional portrait of its author. This chapter presents some of the insights we gain into the varied interests of the chaoben authors. The range of their interests as revealed through the writings and the marginal notes they made on the pages of text, helps to bring out something of their personalities and their perceptions of the societies in which they lived.

\section{Conventional Morality}

Chapters 1 and 2 introduce vocabulary lists, which were welcomed by the illiterate masses because they were texts that could be studied and consulted by the pingmin without the need for a formal classroom setting and without the need for a formal teacher. Vocabulary lists were in abundance from 1850 to the 195 os and constitute the single largest category of chaoben that I have found in the antiques and flea markets in China. Some lists are illustrated though most are simply written words, and many versions printed with lithography or metal type were produced in this period. ${ }^{3}$

For students, the character lists could expand their knowledge in a rational way. Many vocabulary lists prepared for schoolchildren listed items of daily use, from chopsticks to shoes, from cooking pots to hairbrushes. Students beginning

are all bound together in this interesting work, so it is unclear whether this is all the writing of Dr. He or if (perhaps after his death?) some students bound together the piles of his writings that they found. In the eyes of their patients, traditional herbal doctors in China had many curative powers. This psychological and spiritual dimension is discussed in Arthur Kleinman, Patients and Healers in the Context of Culture (Berkeley: University of California Press, 1980), esp. pp. 203-310.

2 The division into professional and personal spheres is probably a more recent Western concept. For the Chinese in the late Qing and the Republican era, one had skills and special knowledge of some things and interests that one found personally fulfilling. I put the words "professional" and "personal" in quotation marks because I think this is an artificial division not used by the population under discussion.

3 The scholar Cynthia Brokaw presents many observations on printed vocabulary lists in Commerce in Culture, in which she refers to them as glossaries. 
a course of formal study could begin by learning how to write the words for items of everyday use. Lists of this type were expanded to include the key family relationships, parts of the body, and basic characters for words such as "house," "store," "gate," and "city wall." Some zazi listed the titles of the chief officials in the government or patriotic terms related to the flag, soldiers, and the nation. Most of the vocabulary lists of this type that I have found were printed versions intended for use in the classroom. The lists could be used in the elementary school classroom or for self-study. As long as a literate person explained the words at least once, the students could repeat and write and memorize the words without further help from a teacher. In that way, students might have begun to lay the foundation for a life of complete literacy, of being able to use conversational language to express themselves about life events in writing. ${ }^{4}$

In order to make it easier to memorize the words, they were usually grouped into sets of three- or four-word verses, and the phrases were often arranged to rhyme. We saw this in Chapter 1 with an illustration from A List of Characters to Teach the People [Shenqun shunzi 申群順字]. The list is bound as a book with twenty-four pages of miscellaneous characters in four-word verses [siyan zazi 四言雜字]..$^{5}$ It contains common words (beginning on p. 3) that young people

4 The illustrated vocabulary lists described in this paragraph were usually printed versions, while the lists copied by hand, which are included in the category of chaoben, did not include illustrations. Among the highly illustrated printed vocabulary lists I have collected, one has a cover that says Vocabulary for Young Students [Youxue zazi 幼學雜字] with the handwritten cover copied by Yan Hailin 閻海林. The full title as printed on the first page is "A New Vocabulary List Illustrated for Young Students” [Huitu Zhonghua youxue xinzazi 繪圖中華 幼學新雜字], which measures $7 \frac{3}{4} \mathrm{in}(18.64 \mathrm{~cm}) \mathrm{h} \times 5 \mathrm{in}(12.7 \mathrm{~cm}) \mathrm{w}$. This book of 18 leaves appears to have been printed in the very early years of the new Republic, probably while Yuan Shikai was president (1912-1915). A similar printed list I have is titled An Illustrated List of Common Words [Huitu suyan zazi 繪圖俗言雜字], which has nineteen leaves and measures 8 in $(20.32 \mathrm{~cm}) \mathrm{h} \times 5^{1 / 4}$ in $(13.34 \mathrm{~cm})$ w. The student who rebound the book in 1941 wrote its title on the cover as “List of Common Agricultural Terms" [Sunong zazi 俗農雜字], with his name, Liu Weisheng 劉衛生. This book was printed in Andong 安東, Manchuria [Manchukuo], in 1936.

5 A List of Characters to Teach the People [Shenqun shunzi 申群順字] is a work of twentyfour pages that was purchased in Beijing in January 2008. It measures $63 / 4$ in $(17.14 \mathrm{~cm}) \mathrm{h} \times 4$ in $(10.16 \mathrm{~cm})$ w, a handy "pocket" size. This work is also discussed in Chapter 1 on contextualizing chaoben. On the first page it gives its title as "Four Word Vocabulary List" [siyan zazi 四言雜 字], which although a generic title, can be taken as its title. In that case the title I have given above would read “Written by Shen Chunshun” [Shen Qunshun zi 申群順字]. The possibility is mentioned in the entry for this title in Appendix A. 


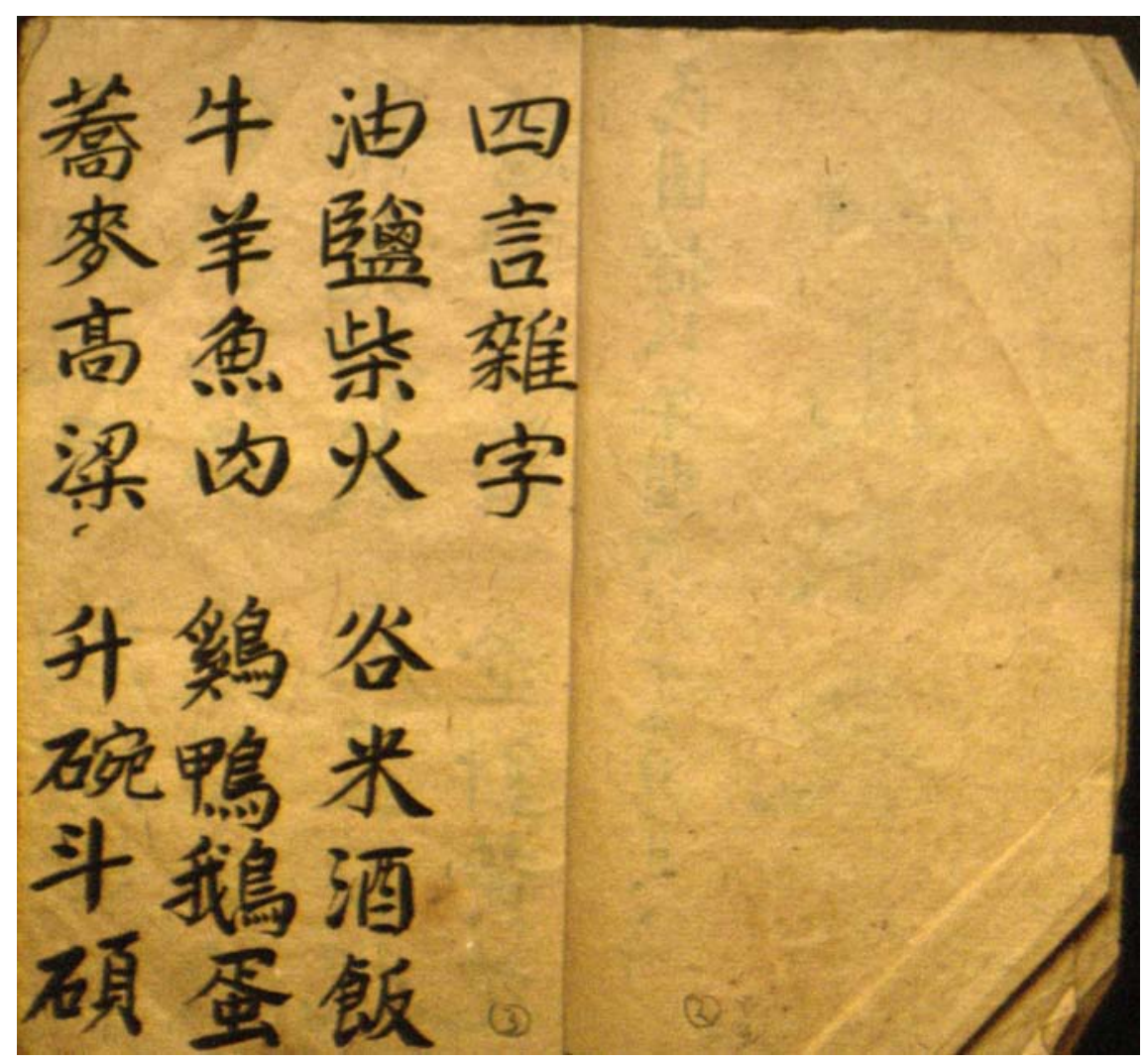

FIGURE 3.1

A List of Characters to Teach the People [Shenqun shunzi 申群順字], Page 3, Common Items for Sale. The text begins with the words “Four-Word Vocabulary List” [Siyan zazi 四言雜字]. This page begins the list of common items for sale in a general store: "Oil, salt, matches; Rice grains, wine, cooked rice. Beef, mutton, fish, meat; Chicken, duck, goose, egg" [You yan chaihuo; gu mi jiu fan. niu yang yu rou; ji ya e dan 油鹽柴火; 谷米酒飯. 牛羊魚肉; 雞鴨我鳥蛋]. Words for a wide range of products and items for sale are introduced. On the final pages are words of advice to honor one's parents, produce children and grandchildren, and enjoy the blessings of a successful life.

Рното вY AUTHOR

needed in everyday life [richang hanzi 日常漢字], especially if they worked at a grocery store.

Oil, salt, matches,

Rice grains, wine, cooked rice,

Beef, mutton, fish, meat,

Chicken, duck, goose, egg. 


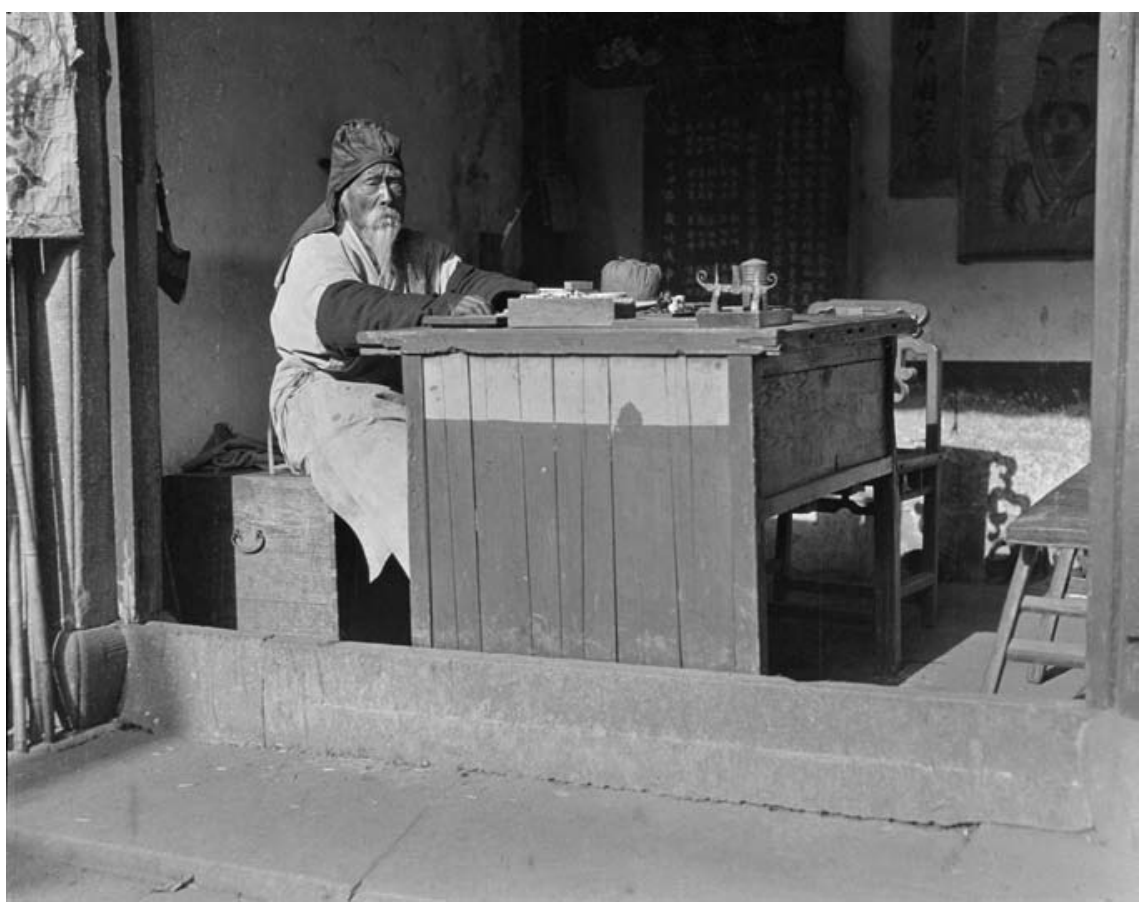

FIGURE 3.2

A Fortuneteller. This fortuneteller was in Hangzhou 杭州 in a photo taken about 1919. He had a small shopfront office, clearly catering to passersby and members of the general public. In the photo, we see on the desk some of his paraphernalia for calculating fate and a bench where his client could sit.

SIDNEY D. GAMBLE PHOTOGRAPHS, DAVID M. RUBENSTEIN RARE BOOK \& MANUSCRIPT LIBRARY, DUKE LIBRARY

\author{
you yan chaihuo \\ gu mijiu fan \\ niu yang yu rou \\ jiya e dan. \\ 油鹽柴火 \\ 谷米酒飯 \\ 牛羊魚肉 \\ 雞鴨我鳥蛋.
}

The entire phrase has a rhyming cadence, and the first and third lines rhyme, as do the second and fourth lines. The special attraction of vocabulary lists for ordinary people was no teacher or a classroom setting was needed for a 
student to learn the material. Any friend who could recognize the characters could read them aloud, and one could read them over and over to memorize the characters. This was an important point for the barely literate who were working to earn their keep and had little time or energy for periods of study.

At this point, I use another previously discussed vocabulary list to comment on the conventional morality supported by most of these chaoben. The value system in premodern China was heavily influenced and elaborately defined by the Confucian perspective. It was an orthodoxy that did not seem to allow for much variation. The outlines of this value system were widely accepted by the illiterate masses seemingly without question. The result was a conventional morality that was cited and repeated in all public situations. In those public spaces, writing or copying a vocabulary list could be counted as entering a public sphere in which conventional morality was expected to rule. Chinese public society took every opportunity to lecture about conventional morality, and the vocabulary lists were no exception. When reading the rhyming sets of words, the reader is advised to read into the logic of the words selected and the message they convey.

In Chapter 1, we discussed Various Words Offered to the People [Kuanzhong $z a z i$ 欵眾雜字]. ${ }^{6}$ This was copied by Guo Changyun [Guo Changyun $j i$ 郭長雲 記] or his relative Guo Shengkui [Guo Shengkui jishu 郭生魁記書]. The Guo family apparently did not believe in subtlety, and they wrote very clearly (especially pp. 20-27) about moral actions and consequences, all in the context of the need to follow conventional morality. This also used in four-word phrases. In general, the second and fourth lines rhyme. ${ }^{7}$ Below is a continuation and more complete version of their comments on morality from pp. 20 and 21 than those that appeared in Chapter 1.

6 The exhortation: "Someday you might commit an offense, It will be hard to protect yourself; The yamen officials will apprehend you, They'll gang up to give you a heavy sentence" [yiri yifan, nanbao shenti; guanya nahu, yanxing kaobi 異日一犯，難保身體；官衙拿獲， 嚴形拷比] is on p. 24. This is part of an explanation of conventional morality, and warns the person of no social standing that the authorities do not protect people of his class. Various Words Offered to the People [Kuanzhong zazi 欵眾雜字] is thirty-page text purchased in Beijing in August 2007. It measures $5^{-1 / 5}$ in $(13.97 \mathrm{~cm}) \mathrm{h} \times 4^{3 / 4}$ in $(12.06 \mathrm{~cm}) \mathrm{w}$ and is a handy "pocket" size. It is also discussed in Chapter 1.

7 The text below comes from Various Words Offered to the People, p. 21. 


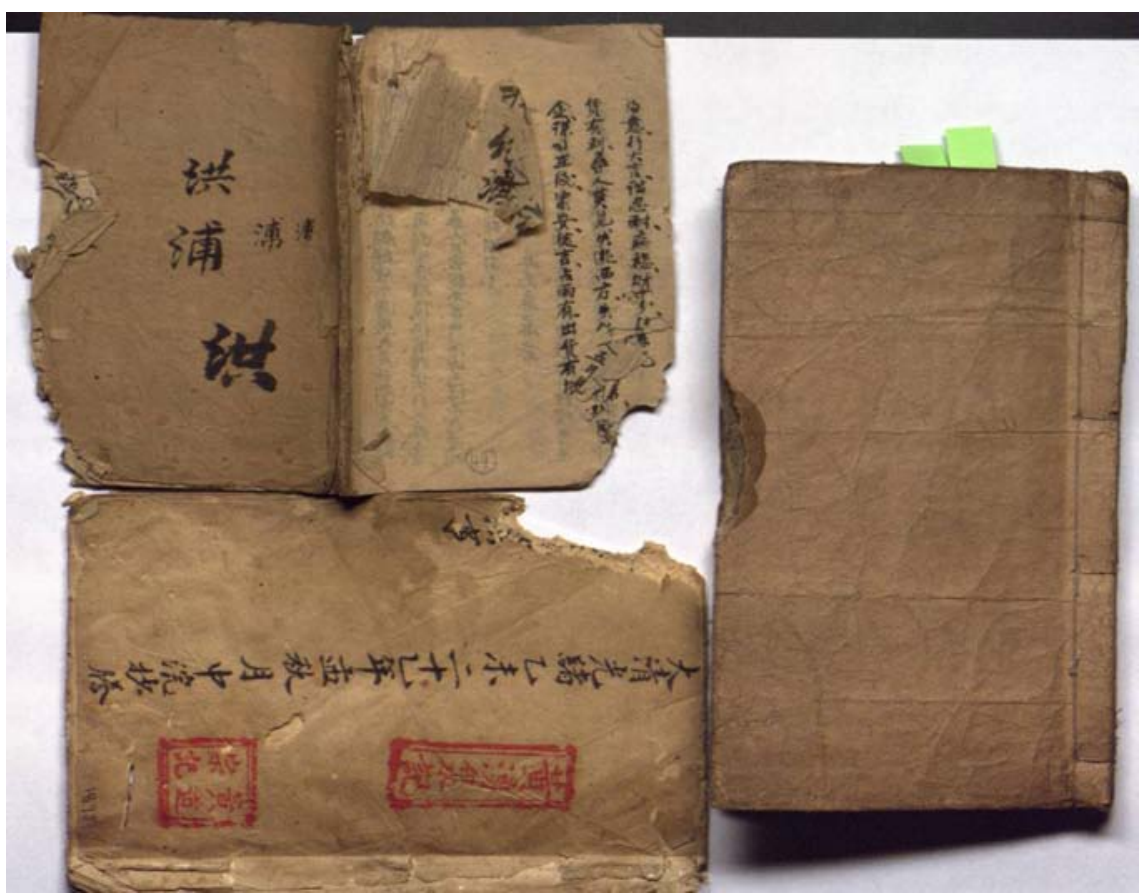

FIGURE 3.3

Damaged chaoben in the author's collection. Chaoben suffered all sorts of damage over the years, from becoming food for insects, to discoloration from human handling, to water damage, to extreme deterioration of the handmade paper. This photo shows chaoben that appear to have been bitten by some animal, such as a rat, a goat, or a donkey. Chaoben were kept in the house, and when the weather was extremely cold, the animals were brought inside for warmth. Like the people, the animals were often hungry.

Рното BY AUTHOR

\title{
Don't steal or do bad things. \\ Don't wear dirty clothes. Cover your body. \\ Avoid torn clothes and serious injuries.
}

\author{
Du bi $\square$ li, qiang duo hu xing 8 \\ Yifu hui wu, tan xi luo cheng \\ Shang shan luan sui, yi ke shang sun.
}

8 The squares seen in my translations are the character "wei." They indicate that a character is missing in the original text. 


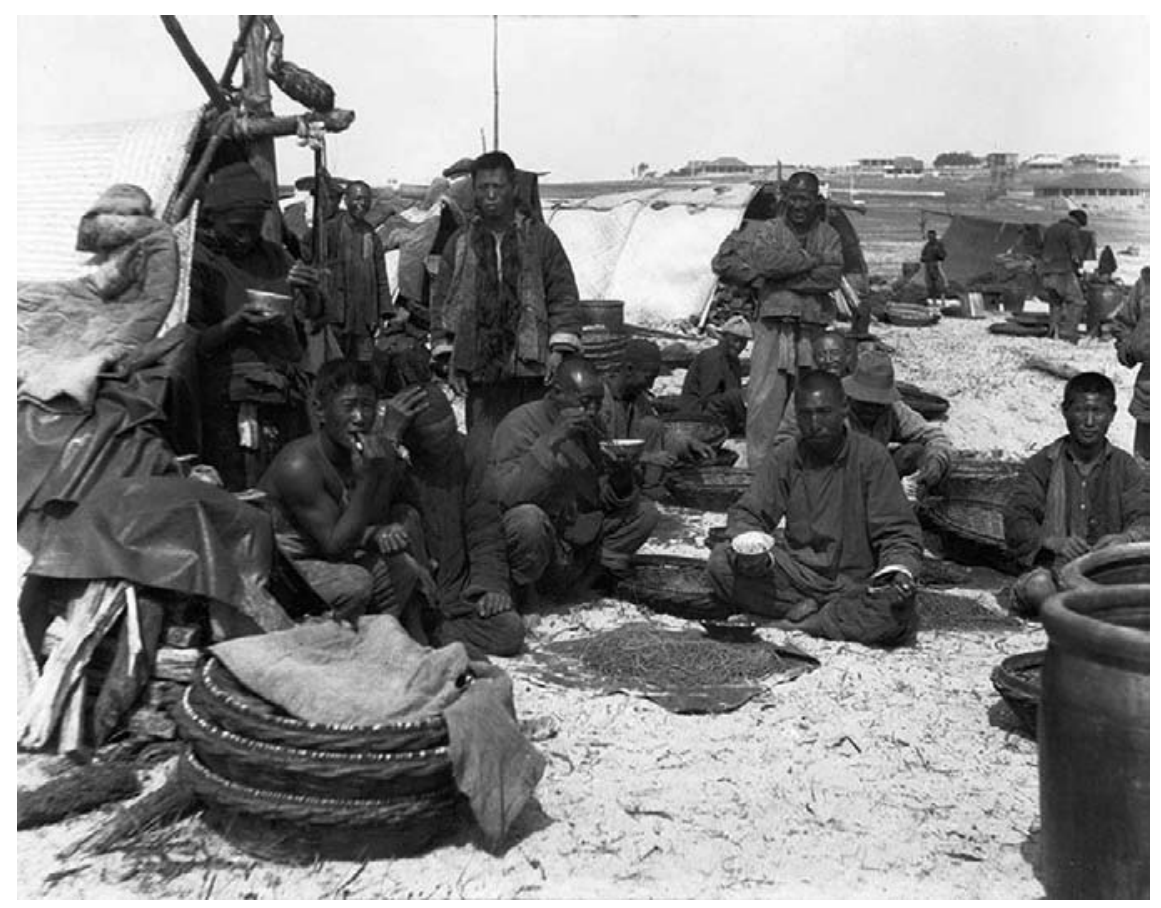

FIGURE 3.4

Laborers. These were the types of young men being addressed in the vocabulary lists when the subject was conventional morality. The text Various Words Offered to the People [Kuanzhong zazi 欵眾雜字] lists instructions on pages 20-27 as discussed in the text. Workers, Western Shanxi. PHOTO: WILLIAM LEETE, 1919; RESTORATION AND PRINT (C)2OO8 WILLIAM MORSE. USED BY SPECIAL PERMISSION.

覩彼口力, 搶奪胡行

衣服穢污, 袒裼裸裎

裳衫攣碎, 呹嗑傷損.

When you get a wound, blood will flow.

Be reserved, try to save money.

Pi kai rou zhan, xue yin lin jin.

$\square$ cun he xi, sheng fei jin yin.

皮開肉綻, 血洇淋津。

口村和息, 省費金銀.

A diligent lad will not imbibe, but be stable in his life. 
Qin jun shao yin, wen zhong yi sheng.

勤君少飲, 穩種一生.

There is no profit in being covetous; if you give in to your (sexual) desires you will harm your own body.

Tan se wuyi, $\square$ ti sun shen.

貪色無益, 口體損身.

Marriage is preordained, never force someone to marry you.

Yin lu qian ding, bu bi qiang hun.

銦綠前定, 不必強婚.

Rape is evil; it will shorten your life and harm society.

Jian yin da e, zhe shou shang feng.

\section{茹淫大惡, 折壽傷風.}

Incest violates all the proper rules.

Wang chang bai huai, fan lv luan lun.

網常敗壞, 犯律亂倫.

Heaven cannot abide evil thoughts.

Ren xin zong fu, tian li nan rong.

\section{人心總伏天理難容.}

In order to appreciate the unequivocal moral aphorisms in this work, we need to go a step farther in our understanding of it. This text was written to be read by a young man. It seems plausible that many of the vocabulary lists were written for a male audience, those who were in paid work. This was clearly not written for sons of the educated literati or high officials. No one would presume to talk 
in this manner to such boys. Rather, this text was written for the common young males who were working odd jobs and perhaps running into village bullies and gang members. The words in this text would be applicable to a boy of the common people.

In Chapter 1 we read Mr. Guo's poem about continually nurturing people. On the last page (p. 29) of the booklet, Mr. Guo also wrote another poem in the regulated verse [lï shi 律詩] style. This style was then and remains today one of the most popular because it is easy to follow the rhythm of the poem and its rhyme. The poem below by Mr. Guo is in the seven-word poem [qiyanshi 七言 詩] style. It is not especially elegant and is typical of a poem composed by an ordinary literate person. The reason I insert it here is that the poem reflects Mr. Guo's concern about guiding and educating youth, which was probably one of his strong reasons for copying his relative's vocabulary list.

This second poem expresses Mr. Guo's personal philosophy. He thought of himself as a very ordinary person (exactly the sort of person who would copy and consult these vocabulary lists). His life, like that of others, was determined by fate, and he expected to confront hardship. The importance of maintaining one's virtue, as expressed in his poem above, is stated again in the following poem (p. 29).

Man is fated to be poor

The only hope comes from keeping filial piety and goodness in his heart What he must do is endure hardship

At the end of the day, he must keep his virtue intact.

Bagui (gua $)^{9}$ shenglai shipinhan

Zhiyao cunxin xiaoyushan

Zongran yanqian shoujiannan

Rihou xinde xingdequan.

八桂(掛)生來是貧寒
只要存心孝與善
總然眼前受艱難
日後心得性德全

9 Mr. Guo wrote gui 桂 [cassia], when he should have written gua 掛 as part of the phrase bagua八掛 [eight trigrams]. 


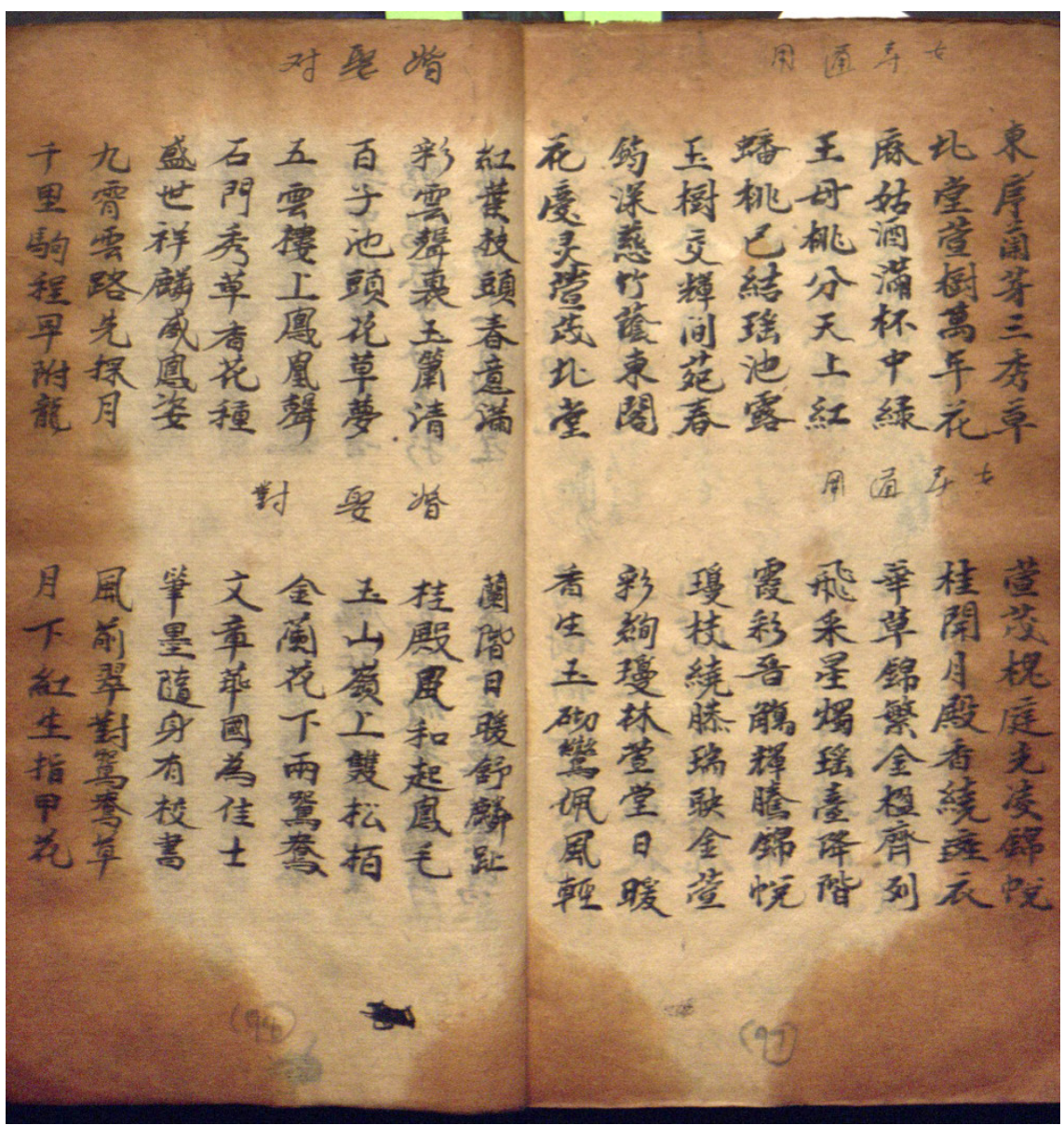

FIGURE 3.5

Celebrating Many Sons. Invitations and Matching Couplets [Tieshi duilian 帖式對聯], Page 98, Matching Couplet. On the left-hand side of the photograph, reading from the right-hand fold, this couplet is vertical lines 3 and 4 on the upper half of the page: "A hundred sons by the pond, a dream of flowering grasses; Five clouds above the pavilion, the sound of phoenixes" [Baizi chitou huacaomeng; Wuyun loushang fenghuangsheng 百子池頭花草夢 ; 五雲樓上鳳凰聲]. Phrases extolling heterosexual marriage and many offspring were common fare in wedding poetry.

РнОто вY AUTHOR

In this poem, the second Mr. Guo expressed his worldview that life is a struggle and that people like him (his implication is "like most of us") were born to be poor. These ideas were a further statement of an attitude of acceptance of the realities of a hard life that were likely shared by most members of the common people. 


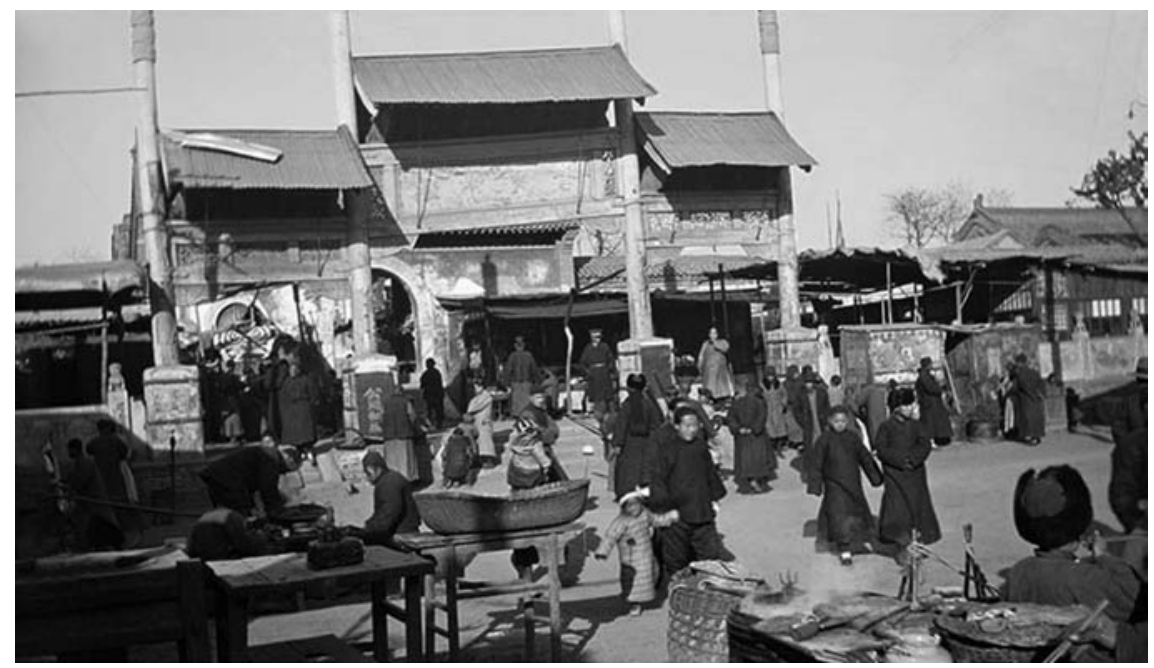

FIGURE 3.6

Temple Fair Market. Popular Buddhist and Daoist temples held a temple fair [miaohui 廟會] at set times during the year. At these fairs, many goods were bought and sold, and fortunetellers, legal experts, herbal doctors, and scribes usually set up tables to offer their services to the general public. Such occasions allowed the illiterate to meet xiucai and others who were literate and willing to offer their services.

MARKET, SHANXI, 1918; PHOTO: WILLIAM LEETE; RESTORATION AND PRINT C 2013 WILLIAM MORSE. USED BY SPECIAL PERMISSION

\section{Marketing among the Pingmin}

Most of the handwritten manuscripts I have collected were used in the course of business. They were part of the exchange of services for remuneration and, so, were used by men trying to make a living using their skills and their ability to read and write. These men knew that it was important to attract and to satisfy a customer who had the money or goods to offer in exchange for the services provided. To that end, the men who wrote these chaoben were happy to state their abilities or the value of the product they could provide. If they were selling their services from a street stall at a temple fair [miaohui 廟會] or village market, they put up a sign or a flag announcing their skills. In addition, they often lauded the products they offered.

Among the fortuneteller's predictions I have bought was one thirty-page booklet titled Using the Western Calendar as a Guide to Writing (Your Fortune) through the Five Stars [Xiyang dili liangtianchi feixie wuxing 西洋地曆 量天尺飛寫五星]. ${ }^{10}$ It predicts the fortunes of a man named Zeng Bingyan 曾

10 Using the Western Calendar as a Guide to Writing (Your Fortune) through the Five Stars 
炳炎. His name is written on the cover, and his seal appears in the margins of several pages. It appears that Mr. Ceng was born in 1871. In 1921, when he was fifty years old, he asked the fortuneteller to predict the next ten years of his life. (This analysis is indicated by his birth date on p. 4 and a phrase on p. 20, “Now you are fifty-one years old" [Mujin wushiyi sui 目今五十壹歲]). Thus this booklet contains predictions for 1922 to 1931. The Chinese characters used in Mr. Ceng's name indicate the strong presence of the fire [huo 火] radical. If Mr. Ceng had been born in 1871, a metal [jin 金] year, his parents may have wanted him to overcome metal as a determinant of his fate, and so they might have given him a name strong in fire, because fire can melt metal. They perhaps wanted him to exhibit the qualities of fire rather than those of metal.

We can postulate that Mr. Ceng's parents did not like the qualities of a metal person: "People with metal personalities are spiritual and have strong morals and high standards. They often hold on to the past and have a hard time letting go of 'what might have been.' Metal people are disciplined and courageous and feel called to help those in need. The metal element is associated with fame. At their worst, people with dominant metal personalities can be unkind, destructive and merciless." Perhaps by giving him a name with the fire radical, they hoped their son would have more of a fire personality: "People with fire dominant in their personalities are energetic and expressive. They do not like to be alone and seek out the admiration and attention of others. Many of them are artistic. Fire personalities are also polite and easily able to reach out to others. They love pleasing others and are good at giving compliments."11

Usually predictions were prepared for a cycle totaling sixty years, which was considered the complete cycle during which the ten heavenly stems [tian'gan 天干] and the twelve earthly branches [dizhi 地支] traverse all the possible combinations and return to their original combination. ${ }^{2}$ However, ten-year

[Xiyang dili liangtianchi feixie wuxing 西洋地曆量天尺飛寫五星] is thirty pages and measures $83 / 4$ in $(22.22 \mathrm{~cm}) \mathrm{h} \times 5^{1 / 4}$ in $(13.33 \mathrm{~cm})$ w. I purchased it in Beijing in September 2005 .

11 These definitions come from the website Everyday Life, http://www.ehow.com/info_ 8408372_characteristics-earth-water-metal-wood.html, accessed July 12, 2014.

12 Some aspects of calculating horoscopes in China using traditional methods are in my article: Ronald Suleski, "Collecting Research Materials in Shanghai: A Qing Dynasty Astrologer's Predictions for the Future," Journal of the Royal Asiatic Society China, n.s., 75, no. 1 (2013). The calendrical system based on the heavenly stems and earthly branches is discussed further in Chapter 9 . 


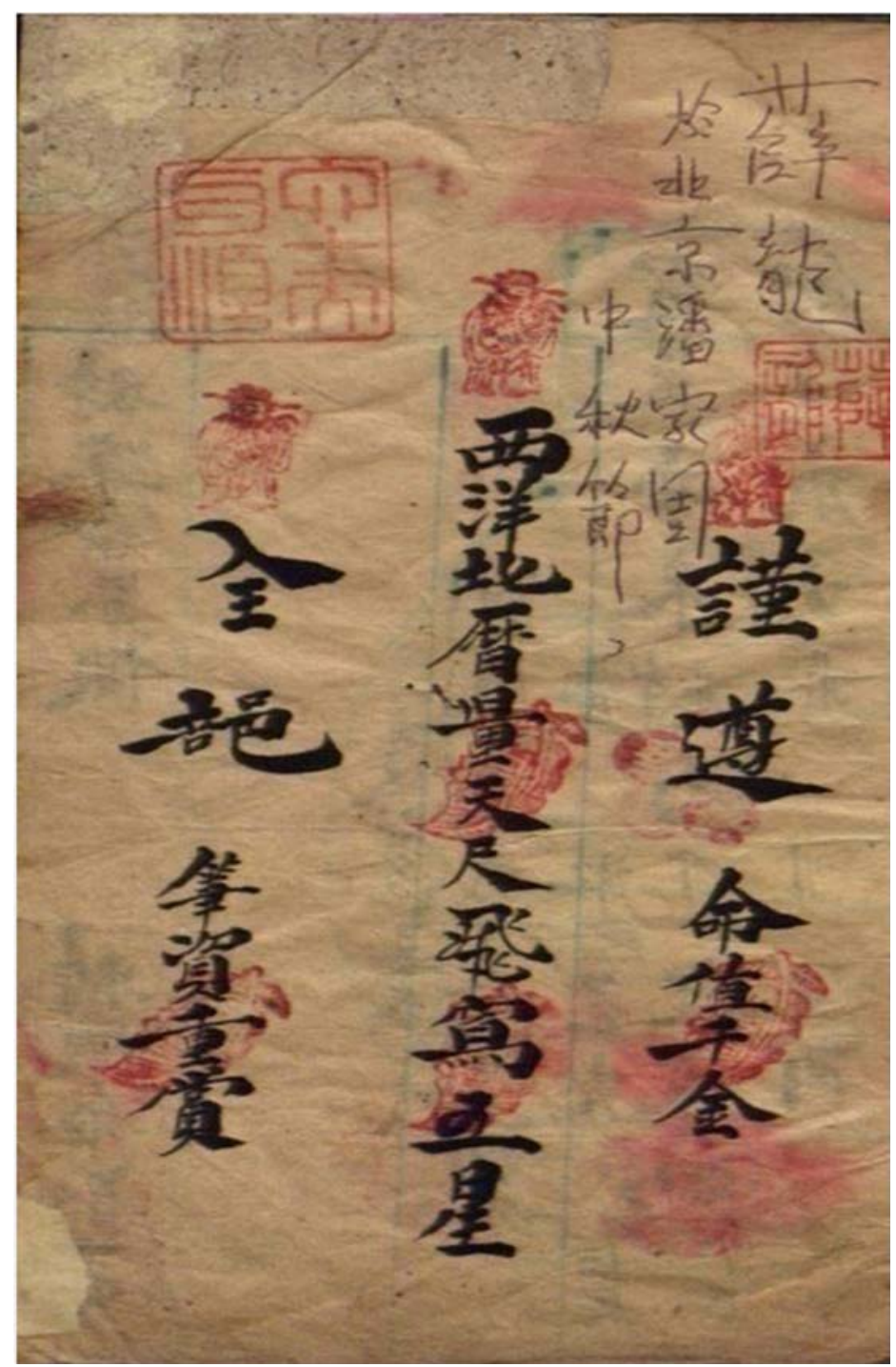

FIGURE 3.7

Using the Western Calendar as a Guide to Writing [Your Fortune] through the Five Stars [Xiyang dili liangtianchi feixie wuxing 西洋地曆量天尺飛寫五星], Cover. The two square seals are personal seals of the author. The "sutra-style" calligraphy and the other seals in red are those of the fortuneteller who prepared this horoscope. It contains predictions for Zeng Bingyan 曾炳炎, who was born in 1871. The predictions are for 1922 to 1931, and this volume was written in 1921.

Pното BY AUTHOR 
cycles were also important in astronomical calculations, and, particularly if $\mathrm{Mr}$. Ceng completed the ten-year cycle by turning sixty, then one can understand why he wanted a set of predictions for that particular cycle.

The predictions made by this fortuneteller indicate that Mr. Ceng was an educated man. He may have worked as a teacher or a writer or in an administrative job. One phrase regarding his future, for example, was "In this time, poems and books [writing] will bring you rewards" [lidang shishu fagui 理當詩 書發貴; p. 16]. Another phrase is: "Excellent Wenchang will reach the ultimate" [Miaoxi Wenchang dingdu 妙喜文昌頂度; p. 20]. Wenchang refers to the Daoist god who assists those working with brushes writing and in intellectual work. A further phrase (half the phrase is given here) is: "On the colorful rock on the riverbank, is Li Bai” [Caishi jiangbian Li Bai 彩石江邊李白; p. 28]. Li Bai (701762 ) is perhaps China's most famous poet and was used here as a symbol of literary accomplishment. ${ }^{13}$

The fortuneteller, who referred to himself as an astrologer [xingshi 星士] who relied on the stars and calculations with numbers, illustrated his written prediction by phrases that were advertisements for the quality of his work. He wrote these phrases and his text using a distinctive writing style called the "sutra script" or "block standard" [xingkai 形楷], in which some strokes are written thickly [made bold] using a heavier stroke of the brush, and he wrote in the right and left outermost margins of the pages. He wrote that he came (or his training came) from Fujian [minzhuan 閩傳]. But he calculated this set of predictions in Nanchang 南昌, Jiangxi 江西 Province. On either side of the vertically written title, he used heavy brush strokes to write that his work offered "Respectful Guidance" [ jindao 謹導]. He reminded the customer that "A Fortune Is Worth a Thousand Dollars" [mingzhi qianjin 命值千金]. He continued on the cover by assuring the customer that his booklet was "Complete" [quanbu 全部]. And he concluded his quatrain by assuring the customer that as an astrologer he was “an award-winning master” [bizi zhongshang 筆資重 賞]. I have not been able to find the name of the fortuneteller in this booklet, but it is clear he understood the importance of presenting an attractive and illustrated booklet. Using light aquamarine blue ink, he drew lines or circles on each page, into which he fit his text or one of the six charts of fate [ mingpan 命 盤] that he had prepared. The strong strokes of the characters written in deep black ink contrasted with the various seals done in an accountant's red ink on many pages. Some of the seals appear to be moths, some are small figures such

13 The deity Wenchang [Wenchang dijun 文昌帝君] is discussed in Chapters 2 and 5. 


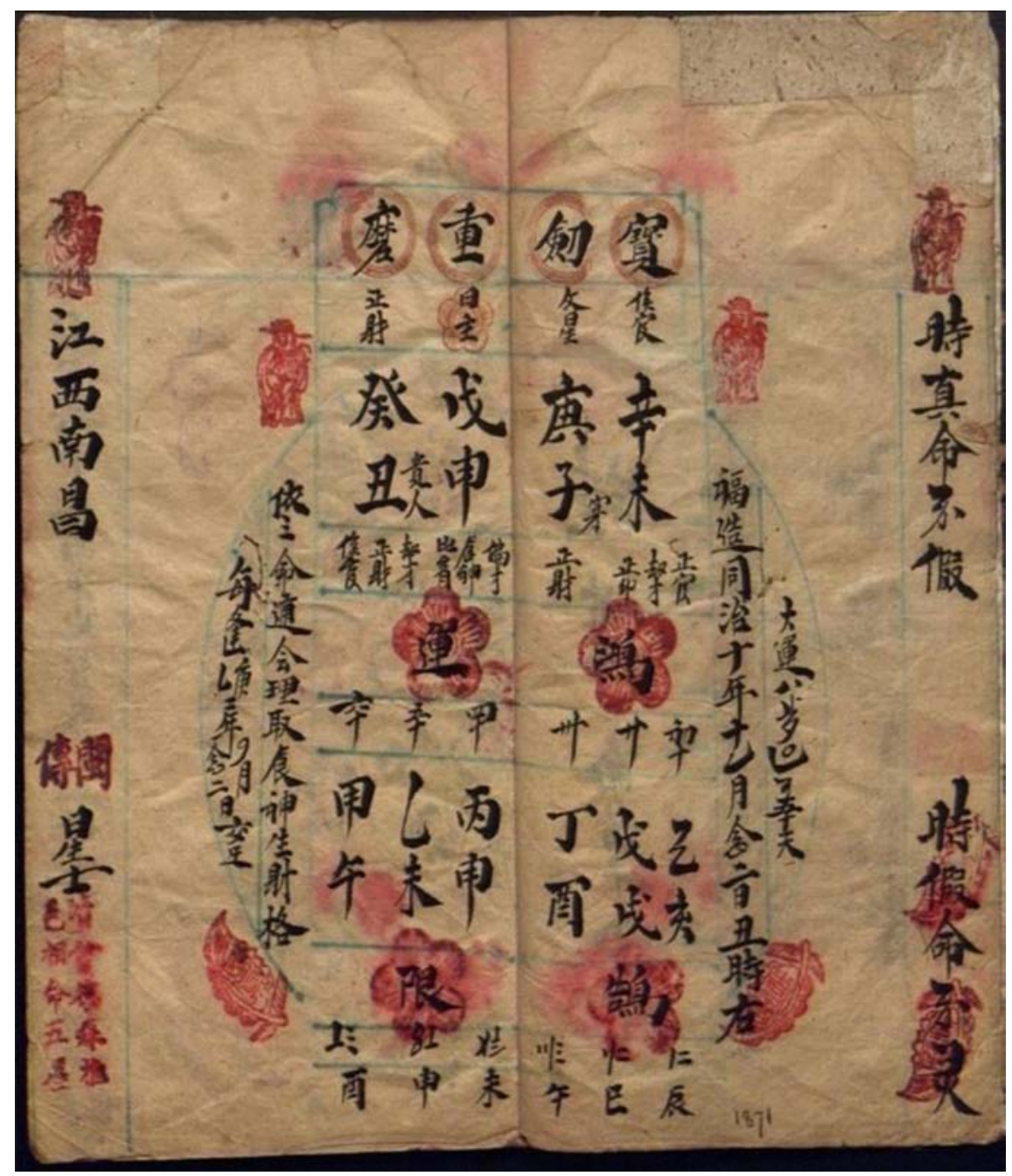

FIGURE 3.8

Using the Western Calendar as a Guide to Writing [Your Fortune] through the Five Stars [Xiyang dili liangtianchi feixie wuxing 西洋地曆量天尺飛寫五星], Pages 4 and 5, Details about the Astrologer. Page 4 gives the year, month, day, and time of Mr. Zeng's birth in 1871. On the lefthand side of page 5, the fortuneteller identifies himself as an astrologer [xingshi 星士] from Fujian [Minzhuan 閩傳] working in Nanchang 南昌, Jiangxi 江西 Province. This fortuneteller may have been moving about the county to offer his services.

PHOTO BY AUTHOR 
as a Star of Good Fortune [Luxing 祿星], and a leaf or feather with the words "Opening Fortune" [Kaiyun 開運]. ${ }^{14}$ The overall effect is colorful and intriguing.

\section{On the Rounds with a Traveling Merchant}

One bound manuscript consists of 114 consecutively numbered pages but lacks its front cover and title page; on an inside cover someone wrote Invitations and Matching Couplets [tieshi duilian 帖式對聯]. This is one of the chaoben I bought in South China with covers (endpapers) of a red-orange color. This type of paper was used from the Ming and Qing dynasties onward in Guangdong 廣東 and other southern provinces. It was treated with insecticide, a mixture consisting of red lead [hongdan 紅丹], sulfur, and saltpeter. Its bright color was called “Ever Red" [wannianhong 萬年紅]. It was toxic to bookworms and was meant to protect the inside pages of the book. ${ }^{15}$ The bulk of this handwritten work consists of the texts for formal announcements, invitations, and congratulatory scrolls that could be prepared for social occasions, such as weddings, birthdays, and funerals. Preparing a booklet such as this was perfect work for an educated person who understood the polite conventions called for during periods of life transitions, when formal announcements needed to be sent out as part of accepted social etiquette. These niceties were widely practiced in China until the advent of the People's Republic, when they were observed in a modified and simplified form.

This book is dated 1907 [dingweisui 丁未歲], which seems an appropriate date for the items inside, especially because of a sample announcement of the return of one's daughter, dated September 1911 (p. 18). To give a date of 1911 for a sample written in 1907 would have not been amiss, but to use the third year of Xuantong [Xuantong sannian 宣統三年, i.e., 1911] after the Republic had been established in 1912 would not have been prudent decision. Thus I accept that 1907 is probably an accurate date. The stamp of the book's owner, Dong Gongda 董恭達, also uses purple ink (not uncommon in the Republican period) on many pages.

14 This is my best guess, after consulting with several scholars, about the characters written inside the leaf. Construction of a Chart of Fate [mingpan 命盤] is discussed more fully in Chapter 5. My thanks to Alister Inglis for help in understanding calligraphic styles.

15 Invitations and Matching Couplets [Tieshi duilian 帖式對聯], which I bought in Guilin in September 2005, measures $5^{1 / 2}$ in $(13.97 \mathrm{~cm}) \mathrm{h} \times 5^{-7} / 8 \mathrm{in}(14.73 \mathrm{~cm})$ w. See Eyferth, Eating Rice from Bamboo Roots, 76 . I also discussed this type of paper with Peking University rare book librarian Lü Shuxian 呂淑賢 in 2016. 


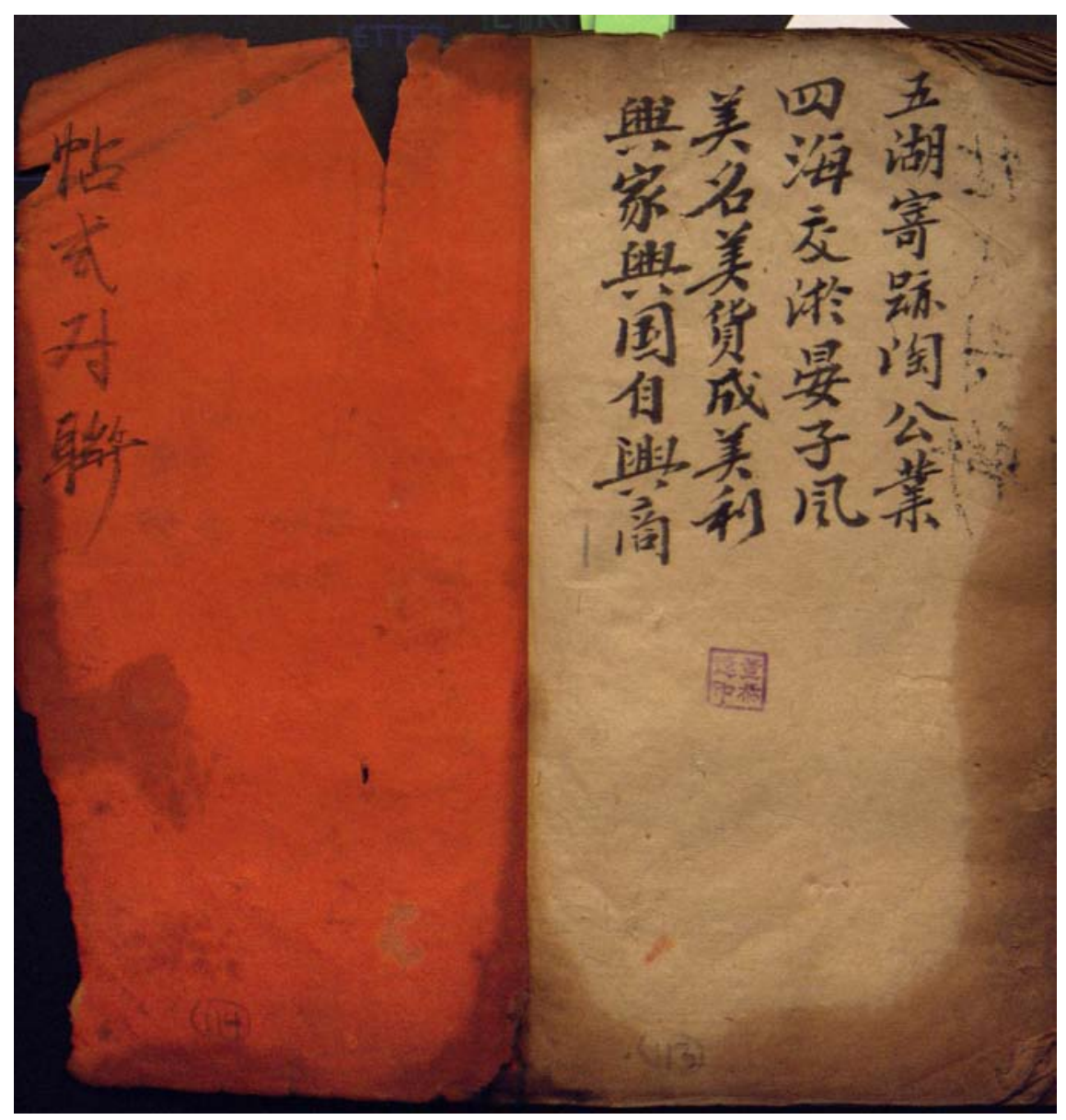

FIGURE 3.9

Invitations and Matching Couplets [Tieshi duilian 帖式對聯], Page 113, Poem on Seeking Work by Traveling about. This page shows a poem written by the person who copied the text in 1907. He began by writing: "Conscientiously doing business throughout the five lakes, Braving the sands of the four seas to catch the late winds” [Wuhu jiji taogongye, sihai jiaoyu yanzifeng 五湖寄跡陶工 業, 四海交淤晏子風]. His ideas are typical of the traveling merchants or itinerant scholars who traveled about the rural countryside seeking income.

Рното вY AUTHOR

Dong Gongda may not have written the contents of this book, which would have indicated that he wrote as a scribe for others. ${ }^{16}$ The darkened coloring of this inexpensive handmade paper indicates it was made for the common

16 It is not always possible to determine from the calligraphy whether a single person copied 
people or, more likely, was used by its author for his own reference in meeting requests from others. However, Dong likely wrote two of the final pages, giving us an idea of what sort of person he was. He may have been interested in the text because he was an educated person, as revealed in his two seven-word lines (p. 111):

The scholar, lost in dreams, creates flowers with his brush

The hermit, sitting in the tower, uses the magpies as a bridge (to greater thoughts).

xueshi mengzhong huazaibi

xianren loushang queweiqiao.

\section{學士夢中花在筆 \\ 仙人樓上鵲為橋.}

I gather from the word "scholar" that Dong Gongda probably saw himself as one. I also perceived that he may have had wanderlust, to go beyond the boundaries that confined him. This intuition was reinforced when I read the complete seven-word shi 詩 [poem] he wrote (p. 113, where he also placed his stamp). Moreover, taking the context of the poem literally, I conclude that Dong Gongda was an itinerant merchant. Such merchants were common in the late Qing period, when many new types of merchandise, such as manufactured goods made in factories like printed cotton cloth, soap, and medicines "imported" from Shanghai and sometimes with a foreign brand, began to be distributed at local markets in inland China. I bought this book in Guilin 桂 林 in South China, which was a natural market area for new products from Guangzhou to the south or Shanghai to the east, delivered by merchants plying the waterways and roads of the region. ${ }^{17}$

the entire contents of a given work. This is because sometimes the same author seems to have written some pages in a different style. We might assume that Dong Gongda got a copy of the book and found it useful, based on his placing his stamp on certain pages. But the two final poems discussed here were clearly added after the main text had been completed.

17 Extensive domestic travel in the course of business was common in China. On itinerant merchants [xingshang 行商 or keshang 客商], see Chia, Printing for Profit, 377-441. The far-flung domestic network of money-changing shops in nineteenth-century China is discussed in Huang Jianhui 黃鑒暉, Shanxi piaohao shi 山西票號史 [History of Shanxi Banks] (Taiyuan: Shanxi jingji chubanshe, 2002). 


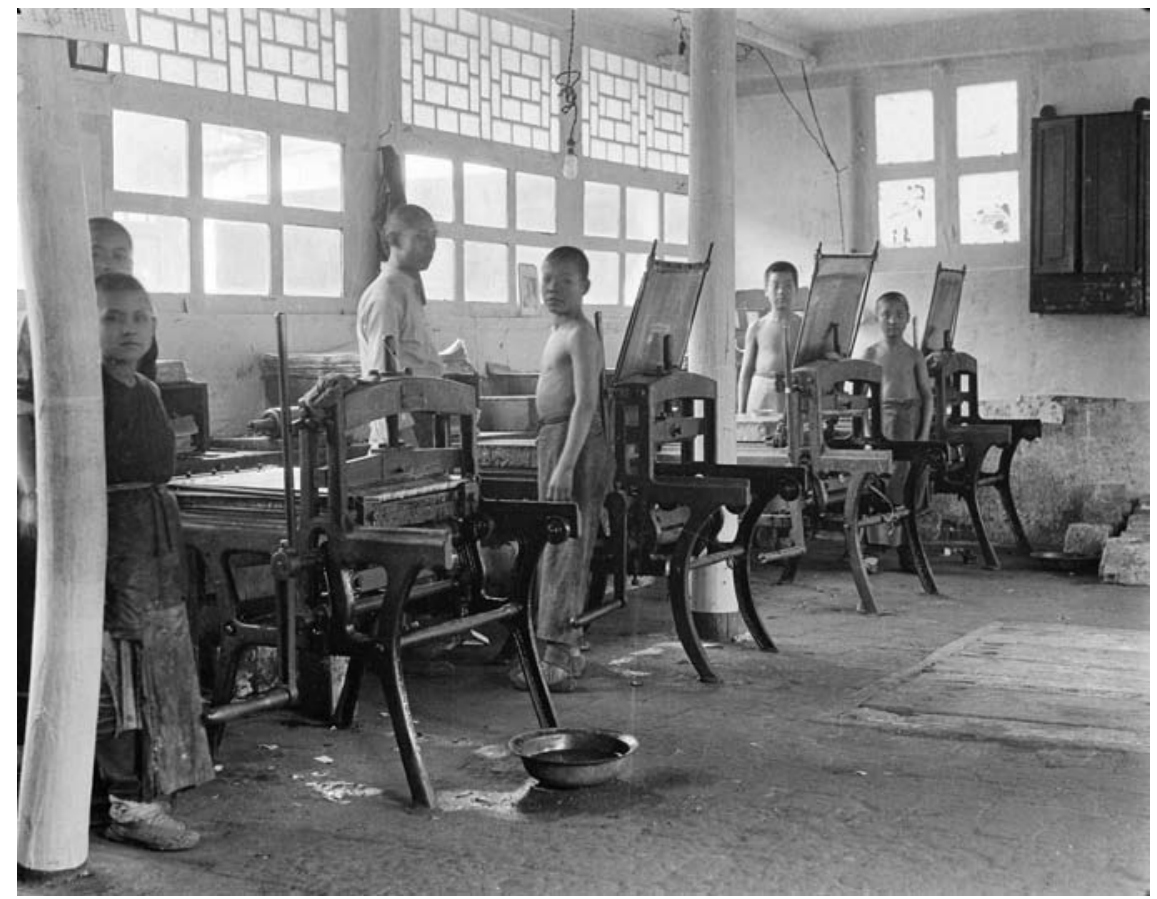

FIGURE 3.10

Training in Lithography. In this photo from about 1919, orphan boys at a Christian school in China are learning printing by lithography [shiyin 石印]. This technique began to be widely used in the West from the 1800 s on, and in China from the mid-to late 1800 s on, it was popularly used to augment traditional woodblock printing. The purpose of the training shown in this photograph was to allow the boys to learn a trade by which they could earn an income.

SIDNEY D. GAMBLE PHOTOGRAPHS, DAVID M. RUBENSTEIN RARE BOOK \& MANUSCRIPT LIBRARY, DUKE LIBRARY

Dong's poem seems to explain exactly what he was doing to earn his income:

Conscientiously doing business throughout the five lakes ${ }^{18}$

Braving the sands of the four seas to catch the late winds

With a good reputation and good products we made a good success

We help our family, our country, and increase our business.

\section{Wuhu jiji taogongye}

sihaijiaoyu yanzifeng

18 "Five lakes and four seas" [wuhu sihai 五湖四海] was a standard phrase indicating "all corners of the land" or "all over the country." See Xinshidai han-ying dacidian, 1631. 
meiming mehuo chengmeili

xingjia xingguo zixingshang.

\section{五湖寄跡陶工業 \\ 四海交淤晏子風 \\ 美名媚貨成美利 \\ 興家興國自興商}

It makes sense that an itinerant merchant would want to keep intact his farflung network of contacts, and he might do this by sending formal announcements and politely worded notes to the people he knew. He would have found a book such as this useful in his business life. It is equally possible he copied the formal announcements from another source and used the book as a reference when he was called upon, perhaps at the periodic markets he visited, to compose a notice or to write a matching couplet. He may have set up a small table at the market to earn income in addition to sales income from goods.

Another book in my collection, a printed book, makes reference to the difficulties of traveling for business and underscores the pride that someone such as Dong Gongda took in traveling for business. It consists of ten lithographprinted folio leaves that I bought in Hangzhou in in 2012. The first words on the first page are Talking about Vocabulary Lists [Shuo zazi 說雜字]. On leaf 6b is written:

Going out, to do business. Run to Nanjing, rush to Beijing. The traveler encounters, slopes and uneven ground, valleys, mountain ranges, sandy beaches, overgrown wasteland, earthen ridges, hollows that are difficult to cross.

Chuwaiqu, zuo maimai. Pao Nanjing, $x$ Beijing. ${ }^{19}$

Zuole xie, tupozi, shuigouzi, shanlingzi, shatanzi, huangdianzi, tukangzi, buwazi.

出外去, 作買賣。跑南京, 闖北京。走了些, 土坡子, 水溝子, 山領 子，沙灘子，荒甸子，土坎子，不凹子.

$19 \mathrm{X}$ is a character I cannot find in the dictionary composed of the radical 鬥 $d o u$, with a horse [ $\mathrm{ma}$ 馬] inside. It is probably the character 闖 chuang, which has the "gate" [men 門] radical and means "to rush about." 


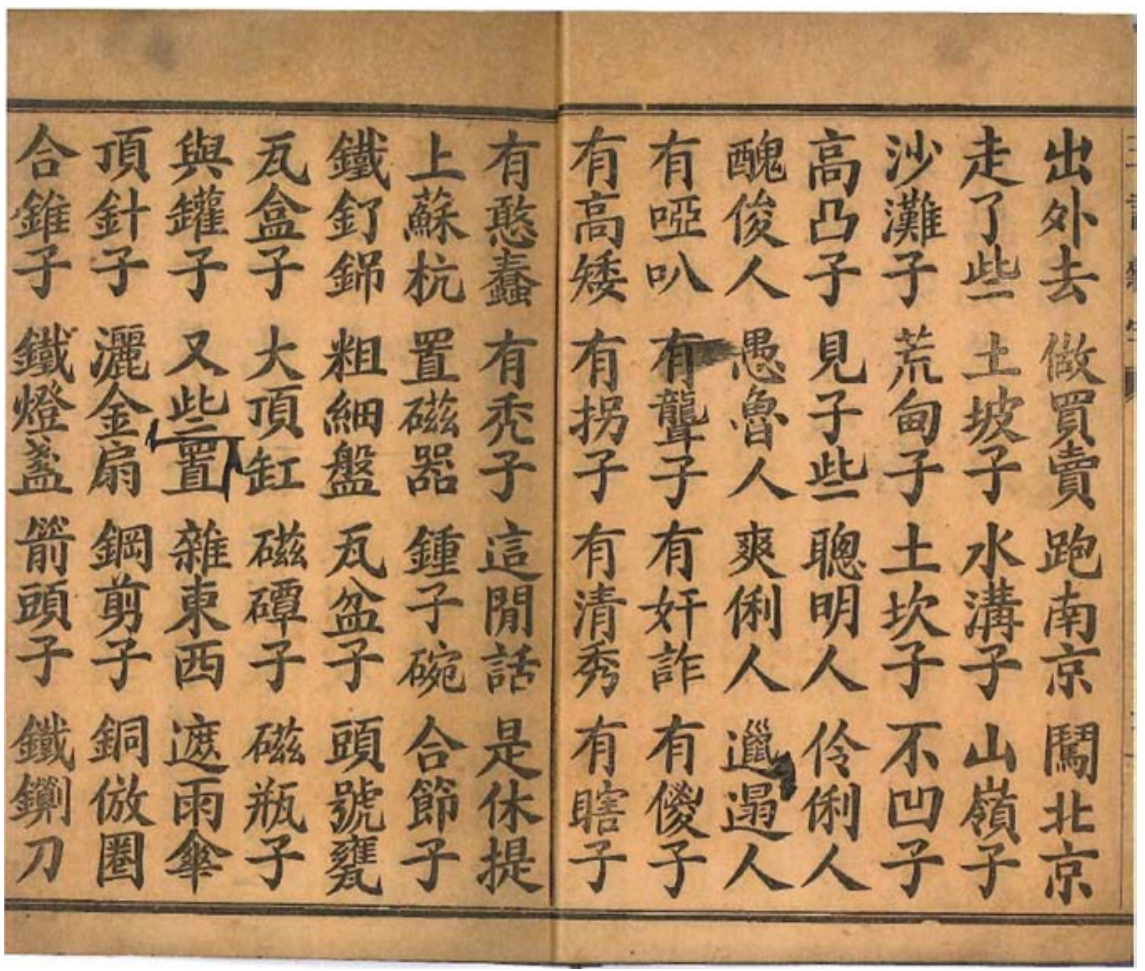

FIGURE 3.11

Talking about Vocabulary Lists [Shuo zazi 說雜字], Leaf 6b, Traveling for Work. We see rhyming phrases about the rigors of frequent travel for the sake of earning an income. The text reads: "Going out, to do business. Run to Nanjing, rush to Beijing. The traveler encounters, slopes and uneven ground, valleys" [Chuwaiqu, zuo maimai. Pao Nanjing, $\mathrm{x}$ (likely miswritten for 闖 chuang, meaning “to rush about”) Beijing. Zuole xie, tupozi ... 出外去, 作買賣。跑南京, 闖北京。走了些, 土坡子].

Рното BY AUTHOR

The descriptions continue. The reference to both Nanjing and Beijing, with Nanjing first, leads me to think this was produced in the early Republic and produced in the south, where Nanjing was a rival capital. Thus judging by the paper used and the lithograph process, the book was written and produced between 1912 and $1927 .{ }^{20}$

20 The book measures $63 / 4$ in $(17.14 \mathrm{~cm}) \mathrm{h} \times 4^{3 / 4}$ in $(9.52 \mathrm{~cm}) \mathrm{w}$. Its official title as printed in the folded margin of the page (the fishtail [yuwei 魚尾]) is Sanyan zazi 三言雜字 [ThreeCharacter Vocabulary List]. For an explanation of the organization of folio pages and the fishtail used on traditional woodblocks, see Chia, Printing for Profit, 43. 


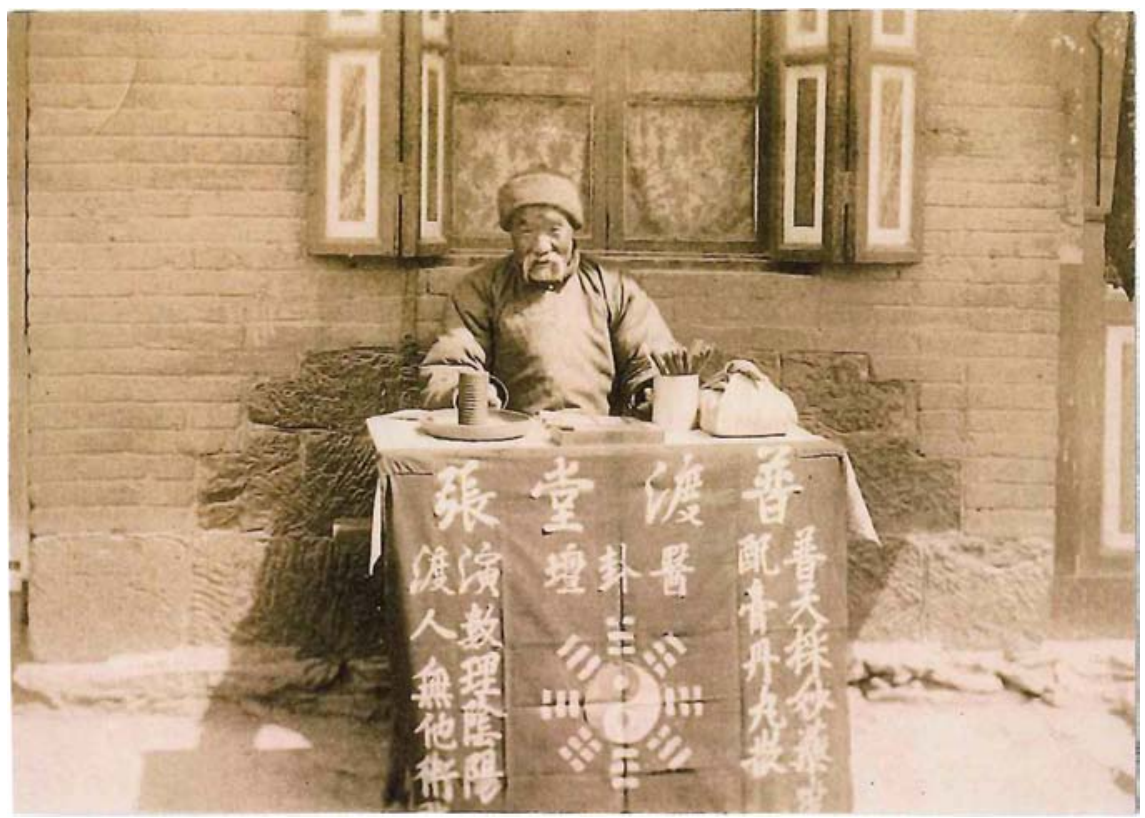

FIGURE 3.12

Yinyang Master. The title of his advertising banner is "Zhang of the Pudu Hall" [Pudutang Zhang 普度堂張]. Pudu means to liberate or to set free from suffering. The writing on the left-hand side of the banner says: "Explaining yinyang" [Jiaoli yinyang 教理陰陽]. All the other wording indicates that his approach is based on the Daoist principals of trigrams [gua 卦]. He could be defined as a type of fortuneteller.

PHOTO: POSTCARD REPRODUCED BY CHINA YOUTH PRESS [ZHONGGUO QINGNIAN CHUBANSHE 中國青年出版社]

Another book in my collection is On the Foundation of Marriage [Hunyuanjiang 婚元講], a work discussed in Chapters 1 and $2 .{ }^{21}$ This is a handwritten compilation that reveals the context of the work through information written in the margins. In this chapter, I offer some ideas about his "specialization," if that term can be used for the pre-195o era, when literate people had a broad notion of their abilities. It was prepared by a man who gave advice on marriage based on the positions of the stars, the eight trigrams, and the effect of the elements on the union of the two parties to the marriage. In that sense, he was a fortuneteller whose calculations could ensure a successful union and future for the couple. But he also talked about the supernatural forces and the spirits that

21 On the Foundation of Marriage [Hunyuanjiang 婚元講] is sixty-eight pages and measures 7 in $(17.8 \mathrm{~cm}) \mathrm{h} \times 4^{1 / 2}$ in $(11.43 \mathrm{~cm})$ w. I bought it in Beijing in September 2005. 
also entered into the lives of human beings, so in that sense he was a yinyang master [yinyang shi 陰陽師] who was prepared to write talismans to keep the ghosts and spirits at bay. He offered a number of them (pp. 22, 37-39, and 5254). A fortuneteller may or may not have offered to write talisman, but a yinyang master surely did. Among the topics addressed in this book are how to make the eight trigrams govern weddings, marriage taboos, unlucky years for a marriage, how to arrange the room for the newly married, and how to place talisman in the room of the newly married. One of the taboos listed is "The maiden cannot marry her father-in-law, As set by all the Stars and Rivers" [weng gu jinhun, tiangang hekui 翁姑禁婚, 天罡河魁; p. 21]. Tiangang 天罡 can be seen as the Big Dipper, chief of all the heavenly constellations, while hekui 河魁 could be seen as source of all the rivers. In this sense, based on the way the taboo is written, the prohibition in question is demanded by the most powerful heavenly forces.

I consulted with a Daoist monk about this book, asking him whether he thought it belonged to a Daoist ritual practitioner or a yinyang master who used general fortunetelling techniques. The Daoist master thought it was used by a fortuneteller offering advice on weddings, but I tend to see it as a yinyang master's work. ${ }^{22}$ It is hard to date this work but assigning it to the Republican period is probably a safe bet. The self-promotion that we are calling "advertising" begins on the front cover, where the master wrote, "this edition is free of mistakes" [wu shi 勿失], and in even bolder characters added, "how to achieve success" [ shumao zhi 樞禁志 $].{ }^{23}$

22 It is not possible to neatly divide and categorize these various approaches of people dealing with the powerful supernatural forces. The Daoist, fortuneteller, and yinyang master may have all been the same person! My goal is to decide on a general proclivity revealed in the work at hand, so as to make a general statement about the person who used the book when giving advice. The Daoist master I consulted was Zhou Xuanyun 周 玄雲, who was living in the Boston area in November 2013, when we discussed this text. If it is not possible to say whether the person using this book was a Daoist priest, a yinyang master, or a fortuneteller. Master Zhou suggested he was surely a general advisor [quandao 勸尊] to people associated with weddings.

23 The word shu 樞 means "pivot," which is an important element in Daoist thinking. It is a concept in which at the juncture of the pivot or hinge there is a complete harmony and unity, even of opposites. The reference to this concept on the cover of my chaoben might have inclined the Daoist master I consulted to see the author of the work in my collection as a Daoist fortuneteller, since this is a philosophical concept of Daoists, rather than as a ghost-centered work, which would be more likely to be used by a yinyang master. On the pivot of the Dao, see Burton Watson, The Complete Works of Chuang Tzu (New York: Columbia University Press, 1968): the unity of opposites through the philosophical pivot 
On the inside pages, the self-promotion continues. The author wrote, "This book is filled with benefit, each word is worth a thousand cash" [shishujieyouyi, yizizhi qianjin 是書皆有益, 一字值千金; pp. 6o-62] and "A thousand cash is easy to obtain, but good advice is hard to get" [qianjin yide, haoyu nanqiu 千金 易得, 好語難求; p. 64]. Later, in the upper margins, he wrote "hard to get" [nan qiu 難求; p. 66] and "beneficial” [you yi 有益; p. 68]. The person who copied and used this book was confident of its value, and he therefore stated his confidence in the upper margins, in order to convince himself or his customer. Perhaps it was part of his sales pitch to the prospective client.

This is the copyist who wrote the phrase mentioned in Chapters 1 and 2: "The xiucai [student] studies yin and yang and, in the process, uses a lamp's worth of oil” [xiucaixueyinyang, yongyouyideng zhan 秀才學陰陽, 用油一燈戔; p. 46]. He studied hard, but as this chaoben demonstrates, he used his knowledge to give advice and to earn income.

\section{The Doctor's Personality}

In May 2012, I was happy to find in a Hangzhou antiques market a thick ( 167 pages) string-bound handwritten chaoben titled Internal and External Medical Complaints [Neiwaike yanke zazheng 內外科眼科雜症]. ${ }^{24}$ In this collection of mostly medical information, a doctor named He Jinliang 何錦樑 compiled his prescriptions for herbal cures. A date of 1932 is written in the book (p. 12), which seems accurate, judging from the paper used. Tucked inside was a thin printed booklet of eight pages titled Practical Cures [Shiyan liangfang 實驗良

is described (in part) as: "Where there is recognition of right there must be recognition of wrong; where there is recognition of wrong there must be recognition of right. Therefore, the sage does not proceed in such a way, but illuminates all in the light of Heaven. He too recognizes a 'this,' but a 'this' which is also 'that,' a 'that' which is also 'this.' His 'that' has both a right and a wrong in it; his 'this' too has both a right and a wrong in it. So, in fact, does he still have a 'this' and 'that'? Or does he in fact no longer have a 'this' and 'that'? A state in which 'this' and 'that' no longer find their opposites is called the hinge of the Way. When the hinge is fitted into the socket, it can respond endlessly. Its right then is a single endlessness and its wrong too is a single endlessness. So, I say, the best thing to use is clarity" (p. 40). The phrase as written on the cover of On the Foundation of Marriage could also be translated as "on enabling the pivot."

24 Internal and External Medical Complaints [Neiwaike yanke zazheng 內外科眼科雜症] is $8 \mathrm{in}\left(20.3^{2} \mathrm{~cm}\right) \mathrm{h} \times 5^{1 / 4} \mathrm{in}(13.33 \mathrm{~cm})$ w. Note that the complete title also includes the words "ocular medicine" [yanke 眼科]. See note 1. 


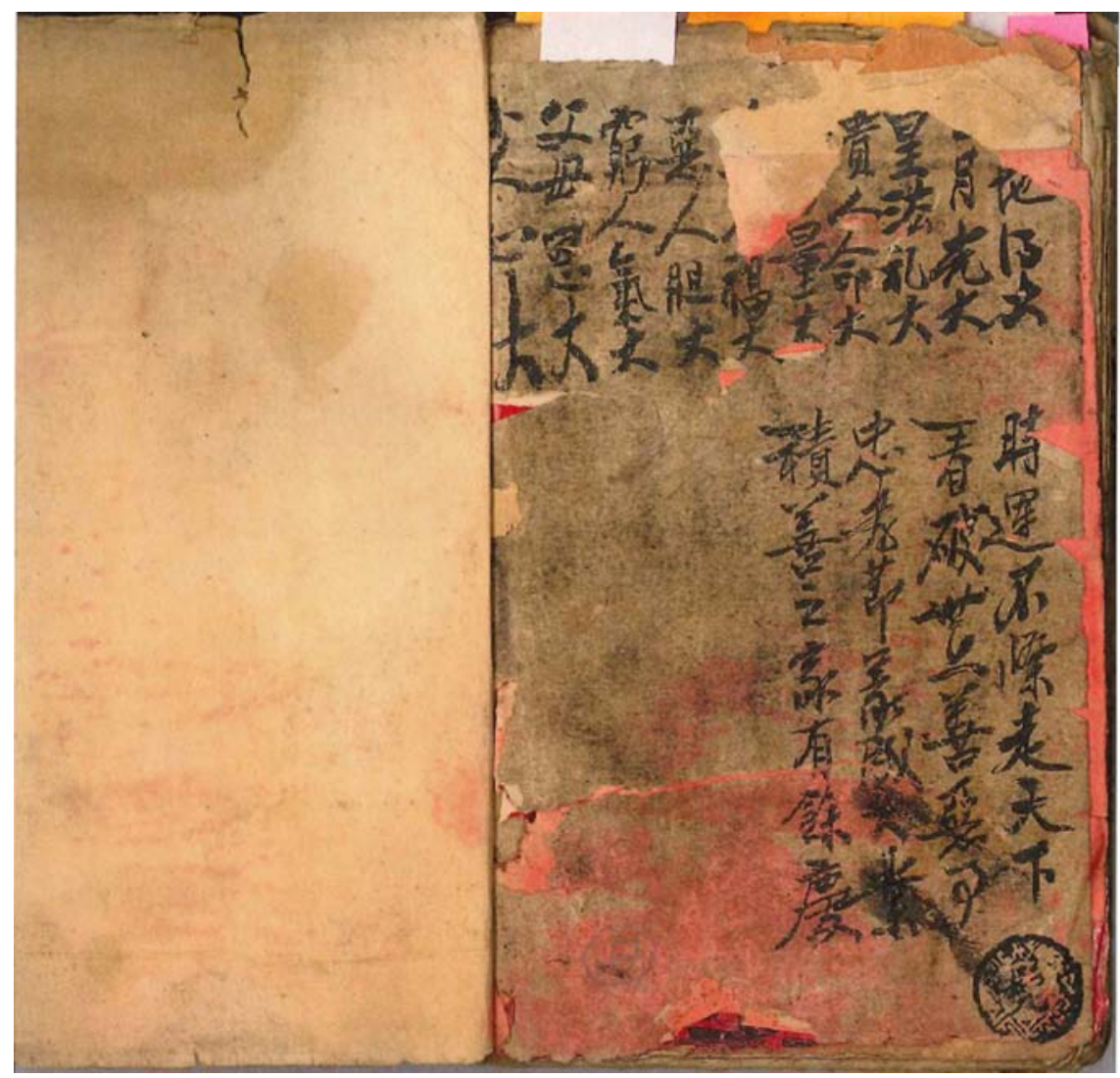

FIGURE 3.13

Internal and External Medical Complaints [Neiwaike yanke zazheng 內外科眼科雜症], Page 167, Simple Truths. At the top of this page are some aphorisms selected by the author: "The august emperor has lavish ceremonies; the rich enjoy a lot of power. Bad people have a lot of gall; the poor have a lot of gumption" [Huangtai lida, Guiren mingda, Eren danda, Qiongren qida, ... 皇汰禮 大；貴人命大；惡人膽大；窮人氣大 ....

рното BY AUTHOR

方], provided free by the Shanghai United Friendship Society [Shanghai lianyishe 上海聯誼社] in 1945. It offered simple remedies for many medical complaints and invited the poor and opium addicts to contact the Society. Thus we can assume Doctor He practiced between 1932 and 1945 in the area of Shanghai.

Doctor He referred to his prescriptions as "secret" [mifang 秘方]. In each case, he described the condition of the patient, then listed his prescription, which was often to be prepared in the form of a pill [wan 丸] or a soup [tang 湯] or served with tea [cha 茶]. He wrote about tuberculosis of the lymphatic glands, anxiety and depression, knife wounds, and boils and sores, among many 
other complaints. One gets the impression from this work that he was a busy and an experienced medical practitioner. On the final page (p. 167), he wrote some aphorisms that he found apt: "The august emperor has lavish ceremonies; the rich enjoy a lot of power. Bad people have a lot of gall; the poor have a lot of gumption. We have heavy obligations toward our parents; the common people have big hearts" [Huangtai lida 皇汰禮大; guiren mingda 貴人命大; eren danda 惡人膽大; qiongren qida 窮人氣大; fumu enda 父母恩大; xiaoren xinda 小人心 大]. His reference to the emperor as a symbol of the highest social position in 1932 some twenty years after the imperial system had disappeared indicates the hold of late-Qing thinking among people in Republican China. ${ }^{25}$

The common people living in rural areas in the early twentieth century had many medical complaints. The poor sanitation led to the prevalence of eye and skin diseases. Digestive disorders were also frequent. As industrialization and urbanization increased in the Republican period, industrial accidents often befell workers. They had their limbs mangled in machines or crushed in railway accidents. Some who still had a queue [bian 辨] even after the downfall of the Qing could get it caught in whirring belts and wheels on the factory floor. Foreign bodies in the eye, severe burns, and scalds were also common. Dr. He's prescriptions covered a wide range of complaints. ${ }^{26}$

Dr. He was kept busy not only because of his medical practice but also because he was involved in activity centered in zhuang 庒, usually translated as "small village." It is possible that Dr. He lent money to farmers in these villages. The word zhuang was often used for businesses in pre-1950s China, so he also might have been running a chain of businesses, pharmacies, or pawnshops (which could have had zhuang as part of their name). On one occasion, he needed to contact the people in his network of clients or employees, so he and three cohorts [Baoren 葆仁, Wenyuan 文元, and Wenxiao 文孝] collected small amounts of money from a number of the zhuang. The place names in the list Dr. He kept (p. 34) are hard to locate with any certainty. Yichang 宜昌 could be the same as the city near Wuhan 武漢, while the zhuang near Nengren 能仁 could be in the vicinity of Hefei 合肥 in Anhui 安徽. That would comprise a wide, but

25 One could say that the decision of the Japanese occupation authorities in Manchuria to place the former emperor Puyi 溥儀 on the throne as the emperor of Manchukuo in 1934 was a reflection of the strength of this idea among many people in Asia at the time. The phrase itself no doubt dates from an earlier time, when there still was an emperor. It seemed appropriately evocative to the author of this text.

26 A thorough review of common medical conditions was recorded by a British doctor working in Hengyang 衡陽 and Tianjin 天津 from 1899 to 1922 in Peake in China:Memoirs of Ernest Cromwell Peake (London: British Library, 2014). 
not unlikely geographic network, all located in "central China." We know what was done with the money, however; on the same page, Dr. He wrote, "Today I went to pay my taxes. I must remember to say a prayer at the local temple" [Jinriyaoqu wanqiangliangx. Xuyao jizhe jishe eryi 今日要去完錢糧口. 須要記 着祭社而已].

Our intrepid Dr. He engaged in yet another activity. He was actively interested in religious Daoism, as revealed most clearly in his writings (p. 45). He first writes of a ritual intended to keep ghosts away, titled "Shooting Swords at Ghosts" [Guishen jianshe fa 鬼神剪射法].

First put on a cap with the eight constellations and seven stars. Wear a ceremonial robe with the nine realms of emptiness [jiu kong 九空] and the eight trigrams. Take up the spirit sword and go to where you will encounter the spirits. Take up the ghost sword and go to where you will encounter ghosts. Take up the spirit stars sword [shenxing jian 神星劍]. Cut down the spirits and ghosts with your sword. I petition Laozi. Promptly, promptly, decree in accordance with the statues and ordinances. [This is an] edict!

Toudai badou qixing guan. Shenchuan jiukong bagua mangpaoyi. Shenjian shenshouqu. Guijian guishouqu. Shou shenxingjian. Zhanduan shenguijian. Wo feng Taishang laojun. Jiji rulvling. Chi!

頭戴八斗七星冠。身穿九空八卦蟒袍衣。神剪神收去。鬼剪鬼收去。 授神星劍。斬斷神鬼剪。我奉太上老君。急急如律令。敕! 77

Dr. He wrote another Daoist ritual on the same page, one that asks the follower to be equally active in carrying out the ritual. It was called "Backing Away from Earth to Establish the Law" [Tuitu shefa 退土設法].

On an auspicious day, go to the East, then first step back to retreat from the East. From the jiayi symbol of wood. Second, retreat from the south and the bingding symbol of fire. Third, retreat from the west and the gengxin

27 Jiji rululung [急急如律令] indicates that this is a ritual incantation addressed to the deities. It is usually translated as "Promptly, promptly, decree in accordance with the statutes and ordinances!" It is a standard way of concluding Daoist incantations [zhou yu 咒語]. See Zhang and Wu, Daojiao fuzhou xuanjiang. See also Miura Kunio 三浦國雄 in The Encyclopedia of Taoism, ed. Fabrizio Pregadio (London: Routledge, 2008), 1:117. More discussion of Daoist incantations and their standard wordings is in Chapters 8 and 9 . 


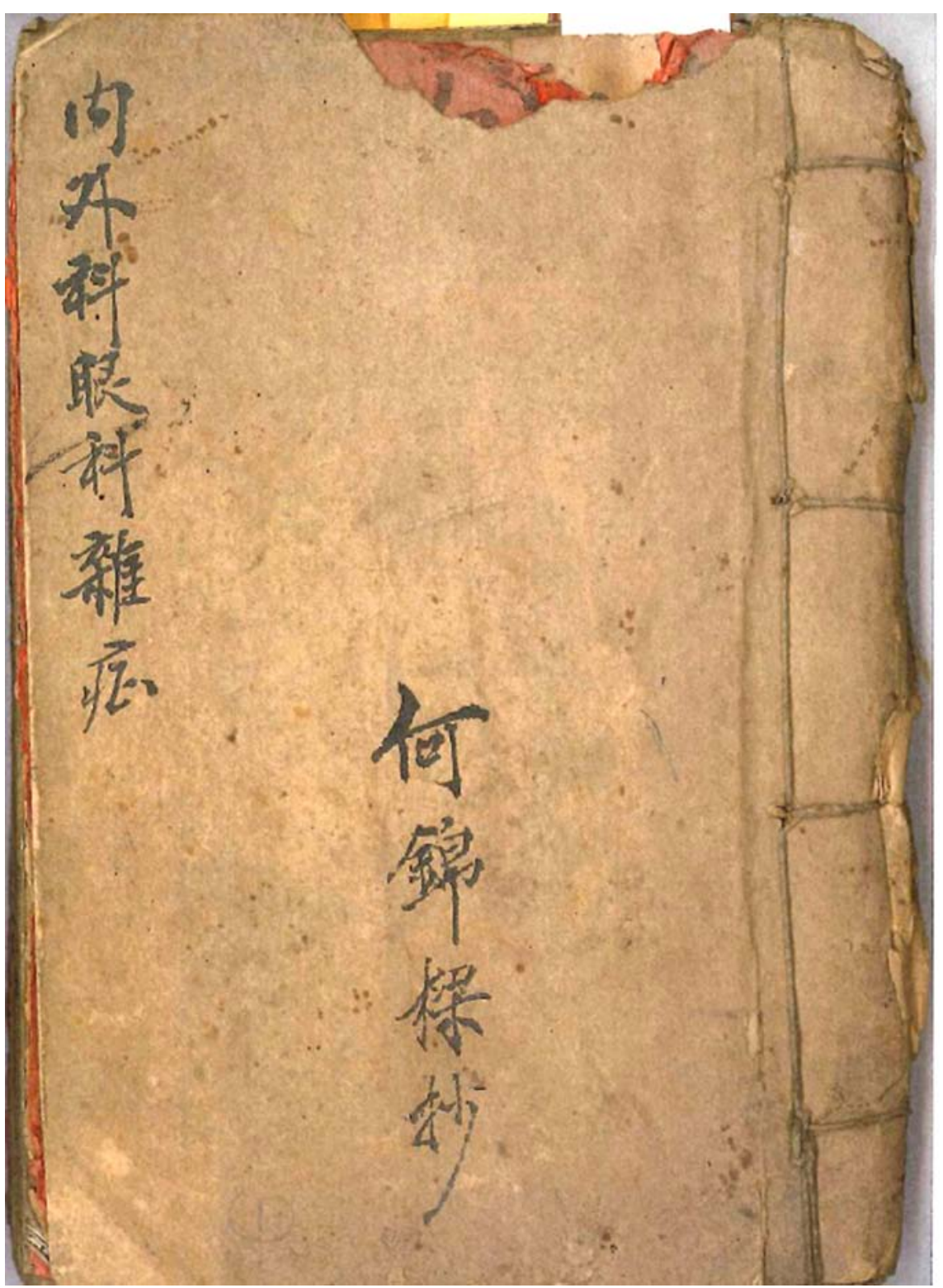

FIGURE 3.14

Internal and External Medical Complaints [Neiwaike yanke zazheng 內外科眼科雜症], Cover. The complete title also includes "ocular medicine" [yanke 眼科].

Рното вY AUTHOR 
symbol of metal. Fourth, retreat from the north and the renkui symbol of water. Fifth, retreat to the center with its xusi symbol of earth. Earth is for all. Grandmother Earth, Son Earth, Grandson. Where there is earth we retreat from earth to where there is no earth. Retreat from the Five Directions and the bad forces. I petition Laozi. Promptly, promptly, decree in accordance with the statues and ordinances This can be recited seven times.

He $x$ yang zhi ri, qu dong fang. Yi, tui dongfang, jiayimu. Er, tui nanfang bingdinghuo. San, tui xifang gengxinjin. Si, tui beifang renguishui. Wu, tuizhongyang xusitu. Tu gong tu. Potu zitu, sun. Youtu tuitu, wutu. Tuiwufang eqi. Wo feng Taishanglaojun. Jijirulvling. Chi!

\section{嚇口陽之日, 出東方。一, 退東方甲乙幕。二, 退南方丙丁火。三, 退西方庚辛金。四, 退北方王癸水。五, 退中央戌巳土。土公土。 婆土子土孫。有土退土無土, 退五方惡氣。我奉太上老君。急急如律 令。敕!}

This is a purification ritual. Each direction has its own forces of good and evil. It is necessary to retreat from the evil forces lurking in each direction, following the Chinese directional order of east, south, west, north, and center. Once in the center, call upon the highest deities to set up a pure zone. In the Qing and Republican period, it was considered perfectly natural for a medical practitioner to be interested in Daoism as well. The doctor was seen as an educated person with full literacy and a wider world view than the typical person. Dr. He no doubt saw his involvement with Daoism as natural, because it was in the spirit of healing both the body and the spirit. This holistic view of existence was generally accepted. Both the herbal doctor and the ritual specialist were interested in helping their fellow human beings. They were not constricted by an assumption of their highly specialized, narrower "professional" pursuits, as would be common in the present.

28 See Zhang and Wu, Daojiao fuzhou xuanjiang, 10-11, in their discussion of the "Incantation to the Five Directions to Protect the Spirit” [Wufang weiling zhou 五方衛靈咒]. I am grateful to Dr. Zhou Donghua 周東華 of Hangzhou Normal University for a helpful discussion about the Daoist rituals presented in this section. 


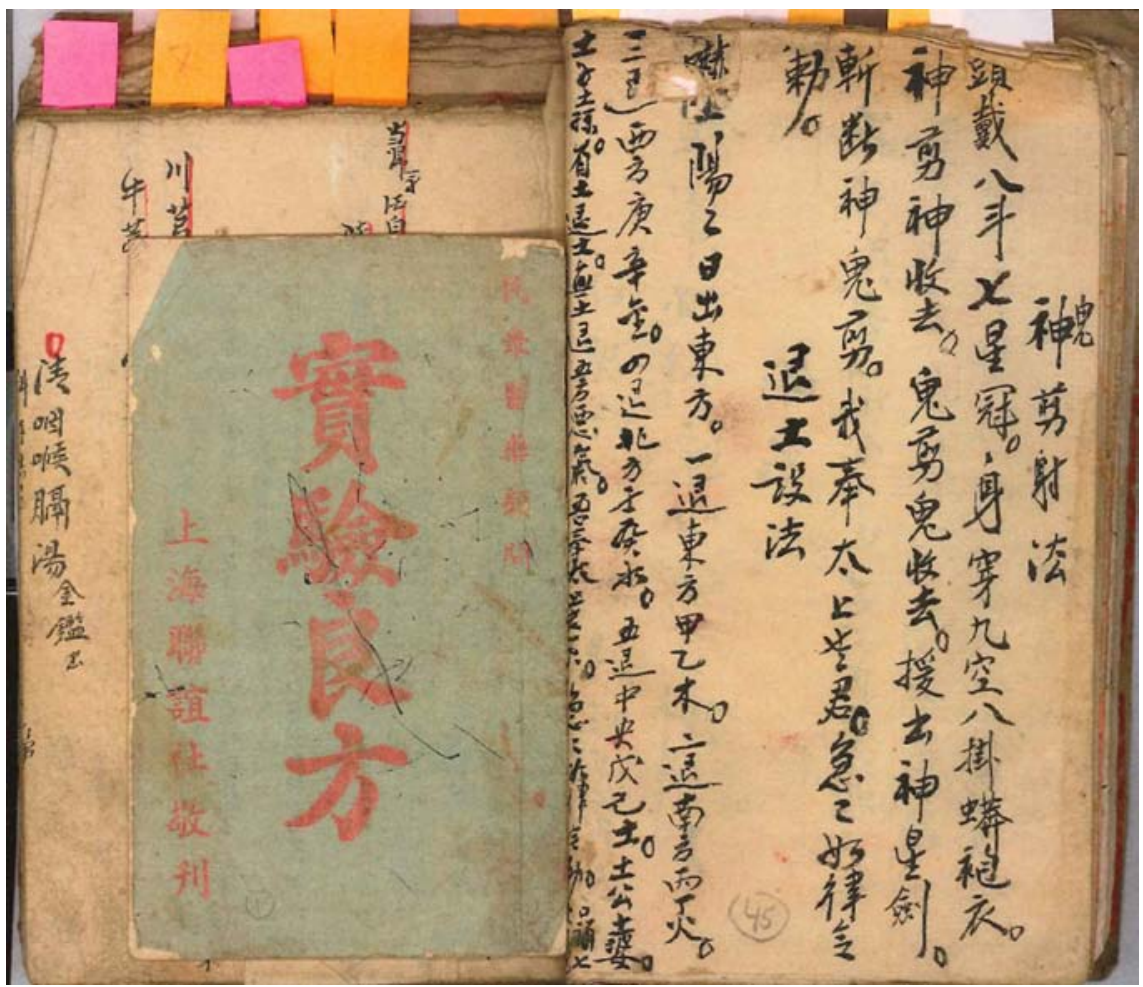

FIGURE 3.15

Internal and External Medical Complaints [Neiwaike yanke zazheng 內外科眼科雜症], Page 45, Daoist Ceremonies. On this page, Dr. He wrote about how to conduct Daoist ceremonies to expel evil. Tucked inside this book was a thin printed booklet, seen on the left-hand side of the photo, of eight pages titled "Practical Cures" [Shiyan liangfang 實驗良方] provided free by the Shanghai United Friendship Society [Shanghai lianyishe 上海聯誼社] in 1945.

Рното BY AUTHOR

\section{Conclusion: Reading into Texts}

It appears that every time a person picked up a writing brush and wrote words in these chaoben, they were committing to paper something about themselves. For example, the quality of their calligraphy allows us to estimate the amount of formal schooling they had and the amount of time they spent practicing how to write characters correctly and neatly. It is not uncommon to find chaoben with poorly written characters, where the balance of the character or the line of each stroke indicates a student of relatively little formal education. At the same time, regardless of the subject matter, many chaoben show that the person who wrote the text had spent a number of years writing with a brush. The number of characters used, some of great complexity, 
also indicate a person who was able to spend a lot of time perfecting his writing skills. Some handwritten texts that show a lot of nonstandard "popular" [su 俗] characters or texts with a "mistaken" character with the same sound as the intended character, which indicates a person who struggled to produce the standard characters. Most likely, this is the mark of a limited formal education.

In one way or another, many of the people who prepared chaoben took the opportunity to reveal something of their personality or set of values. Through the textual material they included, as in the case of Various Words Offered to the People, they were straightforward in listing the values and actions they expected to be adopted by young men in order to lead a moral life. Their instructions were extremely practical and taken from the rough-and-tumble economic strata that called for hard physical labor. I refer to the values they espoused as conventional morality. This is not meant to criticize or dismiss their words but, rather, to state that, without intellectual or philosophical elaboration, these values were generally accepted among the common people of China at the time.

The literate men involved in writing chaoben wished to express themselves through literate skills such as writing poetry. Many of the chaoben I have collected contain poetry, often at the end of the volume, composed by the author or copyist of the volume. I characterize these poems as conventional or commonplace, again, not as a criticism but, instead, to say that they are not filled with obscure literary illusion, as was sometimes favored by highly educated literati. The poems used standard phrases to follow standard poetic rhyme and meter. At the same time, the poems illustrate the viewpoint of its author, such as the phrases "Man is fated to be poor" and "What he must do is endure hardship." If I had a conversation with Mr. Guo, I feel as if I already know how he looked at the world.

The chaoben writers also felt free to write in the margins of their texts. The xiucai who wrote in On the Foundation of Marriage about burning a lot of lamp oil in the course of his studies told us exactly how he felt about them: they required a lot of effort but had a lot of value. He wrote about the value of his studies later, where he mentioned "a thousand cash" [qian qian 千 錢], a standard phrase used to indicate a lot of money. Every time they wrote something of themselves, including the astrologer who in Using the Western Calendar as a Guide to Writing (Your Fortune) through the Five Stars called himself "an award-winning master," we can appreciate the self-image of the chaoben writer. These people were proud of their literacy, their ability to read and write, and the skills they offered to the public. They felt comfortable with this form of marketing or self-promotion. Even when their economic position, 
as educated people who needed to offer their services to the general public in order to earn money, was not always solid, their social position as educated people was assured.

By including the "professional" material of a specialized nature that they sold to the public to earn an income, along with something "personal" that reflected their own opinions, observations, values, or interests, the chaoben writers display their private or personal interests, especially in the example of Dr. He in his Internal and External Medical Complaints. He filled his chaoben with many pages of medical discussions and prescriptions but also showed that Daoist practices also had a place in his life. His factual medical observations about the medical cases he encountered are very different from the symbolically constructed religious worlds he presented in writing about religious Daoism. Shanghai in the 193os was a driven, demanding, and dangerous urban environment for those who lived and worked there. Dr. He illustrates how he coped with life at a challenging time.

We can harvest the full richness of these handwritten texts by thoughtfully reading into them the stories they contain. They were not produced in a vacuum. They were not the fanciful creations of a person with leisure to slowly compose texts. Just the opposite, they were concretely linked to the everyday, workaday world of the common people. They held information the common people needed to know. Yes, they held information the chaoben writer was offering for sale to customers or clients. But in doing so, the chaoben writer made little attempt to hide or disguise his own personality, values, or worldview. The comments in the marginalia suggest to us the individuality of the writer and we can imagine the impression he made on the people meeting with him. The interaction between the copyist, the chaoben with the information it held, and the client can then take on a nuance and vitality as we reconstruct the scene in our minds. When we form this reconstruction based on a thoughtful consideration of the information given in this book, we can bring alive with some accuracy the common people of China in the pre-People's Republic period and their relationship to these chaoben. 